\title{
The Relationship Between Social Environments and Smoking Behavior in Adolescents in Taccorong Village, Gantarang District
}

\author{
Nadia Alfira ${ }^{1}$, Muriyati2 ${ }^{*}$, Irma ${ }^{3}$ \\ Departemen Surgical and Medical Nursing, Stikes Panrita Husada Bulukumba, Indonesia ${ }^{1}$ \\ Departemen Surgical and Medical Nursing , Stikes Panrita Husada Bulukumba ,Indonesia ${ }^{2}$ \\ S1 Nursing Study Program, Stikes Panrita Husada Bulukumba, Indonesia ${ }^{3}$
}

Corresponding Autor : Muriyati.stikes@gmail.com*

\begin{abstract}
Smoking behavior is influenced by several factors, one of which affects smoking behavior in adolescents is the social environment. The results of a preliminary study stated that many adolescents in Taccorong Village smoked because they were influenced by the number of smokers in the environment around the teenagers. This study aims to determine the relationship of the social environment with smoking behavior in adolescents in Taccorong Village, Gantarang District, Bulukumba Regency in 2017. This study is an analytic study with cross sectional approach. Sampling is done by total sampling technique. The research sample taken amounted to 52 teenage male smokers in Taccorong Village, Gantarang District, Bulukumba Regency. Measuring instruments used were questionnaires and observations. Analysis of the data used by the Kolmogorov-Smirnov Z test with a value of $\rho=0,000<\alpha=0.05$ or $\mathrm{p}<0.001$. Shows there is a relationship between the social environment with smoking behavior among adolescents in Taccorong Village, Gantarang District, Bulukumba District.
\end{abstract}

Keywords: Social Environment, Smoking Behavior

\section{INTRODUCTION}

In its development, adolescents are very vulnerable to environmental influences. Non-positive socio-cultural environment is a risk factor for adolescents to get caught up in unhealthy behaviors, for example: smoking, drinking alcohol, using drugs, fighting, and criminal acts. All adolescent behaviors that are considered to save this are very risky to their health and safety (Tarwoto et.al, 2010). Smoking is a habit that is harmful to health, but there are still many people who do it even most people or the public started smoking when he was a teenager. Smoking habit was allegedly not only influenced by the incessant cigarette advertisements in the media, especially television, but also influenced by the smallest environment, that is the family, almost $75 \%$ of households in Indonesia have a cigarette expenditure budget, which means there is at least 1 smoker in the household (Cahyo, 2012). 


\section{COMPRABHENSWE HAHW CARE}

Various facts also reveal that the more teenagers who smoke, the more likely their friends are smokers and vice versa. Among adolescent smokers, 87\% have at least one or more smoker friends (Prasetyo and Budiarti, 2014). Cigarettes are an addictive substance, which when used can cause health hazards for individuals and society. Based on PP No. 19 of 2003 concerning securing cigarettes for health (Lisa, 2013). While smoking itself is one of the habits found in society and is a serious health problem. (Cahyo et.al, 2014). According to data from the World Health Organization (WHO) in 2014, the tobacco epidemic has killed around 6 million people per year, 600 thousand of whom are passive smokers. This finding is reinforced by the results of the 2013 Basic Health Research which showed that smokers aged over 15 years were 36.3\%. Most of them are male smokers with a prevalence of $64.9 \%$ and this number is the largest in the world.

The average cigarette smoked per day by residents aged $\geq 10$ years in Indonesia is 12.3 sticks (equivalent to one pack). The current proportion of smokers in Indonesia is $29.3 \%$, with the proportion of the population aged $\geq 10$ years according to smoking habits in South Sulawesi as much as $22.8 \%$ every day smoking, and $4.2 \%$ who sometimes smoke. With an average number of cigarettes smoked in South Sulawesi as much as $14.6 \%$ (Riskesdas, 2013). Ministry of Health data shows that the prevalence of adolescents aged 16-19 years who smoke increased 3-fold from 7.1\% in 1995 to 20.5\% in 2014. And what is even more surprising is that young people (early) have started smoking. Beginner smokers aged 10-14 years increased by more than $100 \%$ in less than 20 years, from $8.9 \%$ in 1995 to $18 \%$ in 2013. As for research on the social environment with smoking behavior conducted by Prasetyo and Budiarti, in 2014 it was found that there was a relationship between the social environment and smoking habits in adolescents in the Antarctic High School Sidoarjo.

In the Taccorong village environment, the population in the village works on average as farmers and construction workers, based on the results of simple observations researchers many residents who smoke on the sidelines of their work not just the adult age even most of them are still classified as adolescents who do not continue their education. Apart from that, many teenagers in Taccorong Village smoke in warkop in Taccorong Village, in hangouts, on the streets, in public places, and even teenagers who smoke in the yard without any warning from parents, from 2,077 people the number of residents in Taccorong Village, 793 smoking and 1353 non-smoking data 
were found. The number of adolescents in Taccorong Village was 440, 190 were male and 250 were female (Data from the village, 2016).

Of the 190 teenage boys 52 people smoke, after interviews with 10 teenage smokers, the average teenager smokes at the age of 15 years, 6 teenagers smoke because they are influenced by the surrounding environment, most of whom are smokers, 3 teenagers who smoke because they are influenced by his friend then tried to smoke, 1 teenager smoked because his friend often teased him as a sissy teenager smoked because he wanted to be considered male. The magnitude of the influence of the social environment on saving behavior one of which is smoking is a matter that must be a concern. Based on the facts and things outlined above, this problem is the background of the researchers to examine "The relationship of the social environment with smoking behavior in adolescents in Taccorong Village

\section{MATERIAL AND METHODS}

This type of research uses a non-experimental design using a cross sectional approach which is an analytical research design that aims to determine the relationship between variables where the independent variable and the dependent variable are identified at one time unit (Dharma, 2013). Population is an object or subject that is in an area that meets certain conditions with research problems (Syamsuddin et.al, 2015)

The population in this study were male teenagers in Taccorong Village, Gantarang District, Bulukumba Regency. With a population of 52 teenage boys who smoke. The sample is a criterion in which the research subjects represent research samples that qualify as a sample (Hidayat, 2014), the sample size in this study were 52 male teenagers who smoke.

The research instrument was a questionnaire sheet in a structured statement to identify the relationship between the social environment and smoking behavior among adolescents in Taccorong Village, Gantarang District, Bulukumba Regency, which will be tested for validity and reliability, and research instruments used to identify smoking behavior, namely by using sheets. observation. The statistical test used is the Kolmogorov-Smirnov Z test. This test aims to see whether or not there is a meaningful difference in proportions between the frequency distributions observed and expected with a significance level of 0.05 . If P-Value $<0.05$ means there is a significant relationship (Ho is rejected) while $\mathrm{P}$-Value $>0.05$ means there is no meaningful relationship (Ho is accepted). 


\section{COMPRABHENSWE HEAH CARE}

\section{RESULTS}

Table 1. Distribution of Frequency of Respondents by Age

\begin{tabular}{lcc}
\hline Age & N & Percentage (\%) \\
\hline 10 Year & 3 & 5,8 \\
11 Year & 1 & 1,9 \\
12 Year & 4 & 7,7 \\
13 Year & 5 & 9,6 \\
14 Year & 5 & 9,6 \\
15 Year & 6 & 11,5 \\
16 Year & 2 & 3,8 \\
17 Year & 11 & 21,2 \\
18 Year & 8 & 15,4 \\
19 Year & 7 & 13,5 \\
\hline Amount & 52 & 100,0 \\
\hline
\end{tabular}

Table 1 above explains that from 52 respondents the highest number of respondents was 17 years old, namely 11 respondents (21.2\%) and the number of respondents at least 11 years old was 1 respondent (1.9\%).

Table 2 Distribution of social environmental frequencies

\begin{tabular}{lcc}
\hline Social Environment & N & Percentage (\%) \\
\hline Good & 32 & 61,5 \\
Not Good & 20 & 38,5 \\
\hline Amount & $\mathbf{5 2}$ & $\mathbf{1 0 0 , 0}$ \\
\hline
\end{tabular}

Table 2 above explained that from 52 respondents there were 32 respondents (61.5\%) who had a good social environment, and 20 respondents (38.5\%) who had a bad social environment.

Table 3. Frequency Distribution of Smoking Behavior

\begin{tabular}{lcc}
\hline Smoking Behavior & n & Percentage (\%) \\
\hline Light & 10 & 19,2 \\
Is & 23 & 44,2 \\
Weight & 19 & 36,5 \\
\hline Amount & $\mathbf{5 2}$ & $\mathbf{1 0 0 , 0}$ \\
\hline
\end{tabular}

Table 3 above shows that out of 52 respondents who became light smokers $(<10$ cigarettes per day), there were 10 respondents (19.2\%), moderate smokers (10-20 cigarettes per day), namely 23 respondents (44.2\%) and heavy smokers (> 20 cigarettes per day) as many as 19 respondents (36.5\%). 


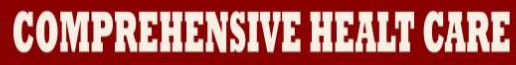

Table 4 Analysis of the relationship between the social environment with smoking behavior in adolescents

\begin{tabular}{|c|c|c|c|c|c|c|c|c|c|}
\hline \multirow{3}{*}{$\begin{array}{c}\text { Social } \\
\text { environment }\end{array}$} & \multicolumn{8}{|c|}{ Smoking Behavior } & \multirow[t]{3}{*}{$P$ Value } \\
\hline & \multicolumn{2}{|c|}{ Mild } & \multicolumn{2}{|c|}{ Medium } & \multicolumn{2}{|c|}{ Heavy } & \multicolumn{2}{|c|}{ Amount } & \\
\hline & $\mathbf{N}$ & $\%$ & $\mathrm{n}$ & $\%$ & $\mathrm{~N}$ & $\%$ & $\mathrm{n}$ & $\%$ & \\
\hline Good & 10 & 100 & 20 & 86,95 & 2 & 10,52 & 32 & 61,53 & \\
\hline Not Good & 0 & 0 & 3 & 13,04 & 17 & 89,47 & 20 & 38,46 & 0,000 \\
\hline Amount & 10 & 100 & 23 & 100 & 19 & 100 & 52 & 100 & \\
\hline
\end{tabular}

Based on table 4 above, it can be seen that from 52 respondents, respondents' perceptions of the social environment category are good with mild smoking behavior of 10 respondents (100\%), good social environment categories with moderate smoking behavior of 20 respondents (86.95\%), environment Association of good categories with heavy smoking behavior of 2 respondents (10.52\%), respondents' perceptions of the category not so good with mild smoking behavior that is 0 respondents (0\%), unfavorable categories with moderate smoking behavior of 3 respondents $(13.04 \%)$, and the unfavorable category with heavy smoking behavior is 17 respondents (89.47\%), Based on the results of the analysis using the Kolmogorov-Smirnov Z statistical test, the value of $\rho=0,000<\alpha=0.05$ or $\mathrm{p}<0.001$ shows the relationship between the social environment and smoking behavior in adolescents in Taccorong Village, Gantarang District, Bulukumba Regency.

\section{DISCUSSION}

Based on research conducted in Taccorong Village, Gantarang District, Bulukumba Regency, obtained in table 5.1 of 52 respondents there were 32 respondents $(61.5 \%)$ who had a good social environment, and 20 respondents (38.5\%) who had poor social relations. . The results of this study are also in line with research conducted by Andrian Liem in 2014 with the results of research showing that friends showed the most powerful influence on adolescent smoking behavior in Yogyakarta compared to the mass media and family. Of the three factors causing smoking behavior, the mass media has the smallest effect according to this study. Because even though television is the mass media that most often presents cigarette advertisements and seen by teenagers, but it appears that it does not affect the smoking behavior of teenagers in Yogyakarta.

According to Irwan in 2010 Environment is a complex system that is outside the individual that affects the growth and development of organisms. While the theory put forward by Yuniya, 2009 says that the social environment is a place for developing behavior towards habits that exist in the environment. A bad social environment will 


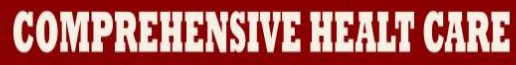

affect the development of one's soul. The bad things he received in the interaction became common to him. Environment and association that is not good can influence someone to violate the norms that exist in society.

As explained by Hadi, 2005 that several aspects can affect adolescent relationships, namely: Family environment such as socioeconomic status, family atmosphere, parenting parents and family support. School environment such as learning activities, social interaction and social communication between school residents and the community environment such as community life patterns, socializing, and mass media. These three aspects are very important war for adolescent association. The assumption of researchers says that most of the respondents have a good social environment, it can be seen from the many respondents who say that parents always explain to their children about a good social environment and teenagers who often get reprimands from parents when smoking, even though there are still teenagers in Taccorong Village, which has a poor social environment, this can be influenced by teenagers who are not open to parents about the problems faced and youth who do not have good relations with the surrounding community.

Based on research conducted in Taccorong Village, Gantarang Subdistrict, Bulukumba Regency is obtained in table 5.2 of 52 respondents who became light smokers ( $<10$ cigarettes per day), as many as 10 respondents (19.2\%), moderate smokers (10-20 cigarettes per day), namely as many as 23 respondents (44.2\%) and heavy smokers ( $>20$ cigarettes per day) as many as 19 respondents (36.5\%).

According to Pieter and Lubis, 2012 Behavior is the totality of a person's visions and reactions that are directly visible or invisible. The emergence of behavior due to the interrelation of internal and external stimulation that is processed through cognitive, affective, and motoric. Understanding of human behavior according to (Irianti and Herlina, 2010) is a manifestation of psychic life and is an activity that arises because of the stimulation and response and can be observed directly or indirectly. whereas smoking behavior itself according to Levy, 2004 is something done by someone in the form of burning and smoking and causing smoke that can be sucked by people around him. The researchers assume that smoking habits among adolescents in Taccorong Village should receive more attention because adolescents are classified as moderate smokers, and some teenagers become heavy smokers. This smoking behavior can occur 


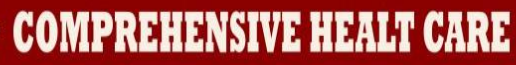

by many people in Taccorong Village who smoke in public places, and do not convince parents to reprimand when smoking.

Based on the results of the analysis using the Kolmogorov-Smirnov Z statistical test, the value of $\rho=0,000<\alpha=0.05$ or $p<0.001$ shows the relationship between the social environment and research published in Taccorong Village, Gantarang District, Bulukumba Regency. In the bivariate analysis results obtained from 52 respondents, respondents' perceptions of the social environment category both with smoking intelligence as many as 10 respondents (100\%), good social environment category with moderate smoking safety as many as 20 respondents (86.95\%), the social environment category is good with smoking habits as much as 2 respondents (10.52\%), respondents' perceptions of categories are not good with smoking habits that are 0 respondents (0\%), categories are not good with smoking habits 3 respondents (13.04\%), and 17 respondents (89.47) \%),

Shodiq, 2014 stated that the association carried out would reflect his personality, both positive relationships and negative relationships. Positive association can be in the form of collaboration between individuals or groups to do positive things. While negative association is more directed to promiscuity, that is what must be avoided, especially for adolescents who are still looking for their true identity. The theory and the results of the study are the same as previous research conducted by Rifan Hendri Prasetyo and Astrida Budiarti (2014) with the title of research: Relationship of Social Environments with Smoking Behavior in Adolescents in Antarctic High School Sidoarjo that almost half of the respondents have unfavorable social surroundings and they said they had a smoking habit, while only 49 respondents or no more than half said they did not have a smoking habit. In a fairly good social environment, only a small portion of them had a smoking habit and only 10 respondents did not smoke. The rest of the overall respondents in a good social environment found only a few who have smoking habits and most dominated by adolescents who do not smoke.

The researcher's assumption says that the majority of adolescents who have a bad social environment are classified as heavy smokers, this can be caused by the large number of respondents aged 17 years at which age teens enter senior secondary education, and adolescents will try to interact with the new environment and copying the behavior of their friends one of which is smoking, besides the lack of attention from some parents will make teens get along with anyone, and teens who do not share the 
problems being experienced when outside the home with parents it will make teens choose to solve the problem by doing negative things one of which smoking.

\section{CONCLUSIONS}

From the results of the study, researchers can conclude that there is a relationship of social environment with smoking behavior in adolescents in the Village of Taccorong, District of Gantarang, Bulukumba. It is expected that taccorong villagers hold routine activities for adolescents so as not to do negative things

\section{REFERENCES}

Aula, Lisa Ellizabet. (2013). Stop Merokok (Sekarang Atau Tidak Sama Sekali). Garailmu : Jogjakarta

Bakar, Sukawati Abu. (2014). Kesehatan reproduksi dan keluarga berencana (dalam tanya jawab) keluarga kecil yang bahagia dan sejahtra. Raja Grafindo Persada : Jakarta

Cahyo et. al (2014). Hubungan Faktor Keluarga Dan Faktor Teman Dengan Perilaku Merokok Mahasiswa Program Studi Ilmu Keperawatan STIKES Ngudi Waluyo Ungaran:Jurnal

Dharma, Kelana Kusuma. (2011). Metodologi penelitian keperawatan. TIM : Jakarta Timur.

Hadi, A. Soedomo. (2005). Pendidikan : Suatu pengantar. UNS Press : Surakarta

Hidayat, A. Aziz Alimul. (2014). Metode penelitian keperawatan dan teknik analisa data. Salemba Medika : Jakarta.

Irwan, Zoer'aini Djamal. (2010). Prinsip-Prinsip Ekologi Ekosistem, Lingkungan Dan Pelestariannya. PT.Bumi Aksara : Jakarta

Irianti, Indah Dan Herlina, Nina. (2010). Psikologi Untuk Mahasiswa Kebidanan. EGC : Jakarta

KNEPK. (2012). Etika Penelitian

Liem, Andrian. (2014). Pengaruh Media Massa, Keluarga, Dan Teman Terhadap Perilaku Merokok Remaja Di Yogyakarta : jurnal

Maulana, Mirza. (2016). Panduan lengkap kehamilan : Memahami Kesehatan Reproduksi, Cara Menghadapi Kehamilan, Dan Kiat Mengasuh Anak. ARRUZZ-MEDIA:Yogyakarta.

Mulyani, Tri Sulati (2015). Dinamika Perilaku Merokok Pada Remaja:Jurnal

Prasetyo, Rifan Hendri Dan Budiarti, Astri (2014). Hubungan Lingkungan Pergaulan Dengan Kebiasaan Merokok Pada Remaja Di SMA Antartika Sidoarjo:Jurnal

Pieter, Herri Zan dan Lubis, Namora Lumongga. (2012). Pengantar psikologi dalam keperawatan. KENCANA : Jakarta

Sari, Riska Timur Ni Nditya (2015). Hubungan Antara Konformitas Teman Sebaya Dengan Perilaku Merokok Pada Remaja SMK Al-Islam Surakarta:Jurnal

Sulistianingsih, Apri (2010). Hubungan Lingkungan Pergaulan Dan Tingkat Pengetahuan Tentang Kesehatan Reproduksi Dengan Sikap Seks Bebas Pada Remaja. Karya Tulis Ilmiyah tidak diterbitkan. Surakarta: Fakultas Kedokteran Universitas Sebelas Maret.

Sujarweni, W. (2014). Metodologi Penelitian Keperawatan. Gaya Media : Yogyakarta Sukmana, Teddie. (2010). Mengenal rokok dan bahayanya. BE CHAMPION. Indonesia 


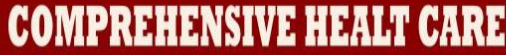

Shodiq, Muh (2014). Pengaruh Pola Asuh Orang Tua Dan Pergaulan Terhadap Kesadaran Anak Dalam Beribadah Dusun Ngasinan Desa Garangan. Skripsi Tidak Di Terbitkan. Boyolali: STAIN Salatiga

Syamsuddin et.al (2015). Pedoman Praktis Metodologi Penelitian Internal. WADE GROUP : Indonesia

Sugyono. (2012). Statistika untuk penelitian. ALFABETA : Bandung.

Tarwoto dkk. (2010). kesehatan remaja, problem dan solusinya. salemba medika : Jakarta

Widiansyah, Muhammad (2014). Faktor-Faktor Penyebab Perilaku Remaja Perokok Di Desa Sidorejo Kabupaten Penajam Paser Utara:Jurnal

Yahya, Yudrik (2013). Psikologi Perkembangan. Kencana prenamedia group : Jakarta 